\title{
Ta Stage Finding
}

National Cancer Institute

\section{Source}

National Cancer Institute. Ta Stage Finding. NCI Thesaurus. Code C96025.

A term that refers to a TNM finding of a primary, non-invasive, papillary cancer. 